\title{
SPIRITUAL LEADERSHIP DALAM PROSES BELAJAR MENGAJAR
}

\author{
Faisol Abrari \\ Kementerian Agama Kabupaten Jember \\ Faisol-coe@yahoo.com
}

\begin{abstract}
Educational institution and Spiritual institution cannot be sterile from disruption era. A good learning process needs good relationship between teachers and students. Good learning process needs high motivation of students, and the teachers must have good motivating ability. Spiritual leadership in learning must be implemented by teacher. The soul of peace, tranquility, sincerity, compassion and perfection will influence in learning process.
\end{abstract}

Keywords: Spiritual leadership, Educational institution

\section{Pendahuluan}

Dalam dunia pendidikan, khususnya pendidikan yang ber "label" Islam dihadapkan pada tuntutan masyarakat yang menghendaki agar mampu menghasilkan output yang benar-benar berkualitas tinggi. Lulusan yang dikehendaki selain menguasai ilmu pengetahuan, skill, dan keterampilan yang dibutuhkan untuk kehidupan yang layak dan sejahtera, juga memiliki bekal pengetahuan agama, moral dan akhlak mulia, serta amal shaleh. Tentunya keseimbangan antara penguasaan iptek dan imtaq adalah suatu keniscayaan yang tidak bisa ditawar lagi. ${ }^{1}$

Para sarjana dan ilmuwan dari seluruh dunia tengah mencari solusi untuk masalah yang menimpa semakinlemahnya kebijakan kepemipinan dan semkin jauhnya kepemipinan dari hakikatnya. Konsep kebijakan, kepemimpinan, dewasa ini tidak mampu menangkap tren memburuk yang terjadi di segala sektor. Suatu era dimana setiap tindakan, transaksi dan/atau interaksi lebih bersifat komersial, hampir semua motivasi didasarkan pada kepentingan diri sendiri, yang akhirnya bermuara pada eksploitasi manusia, dan hal ini sedang berlaku di seluruh dunia. Dalam segala sektor, kepemimpinan cenderung untuk menghan-

\footnotetext{
${ }^{1}$ Ahmad Royani, Internalisasi Budaya Pesantren di Perguruan Tinggi Islam Dalam Melahirkan Intelektual Relegius (Studi Multisitus Universitas Nurul Jadid Probolinggo dan Institut Agama Islam al-Falah Assunniyyah Jember), Proposal Disertasi IAIN Jember 2019
} 
curkan umat manusia daripada mengangkatnya ke derajat dan martabat yang lebih tinggi. Paul Sweezy, seorang pemikir sosialis dengan sarkasme telah menulis bahwa "Para pengusaha telah menciptakan korporasi, sedangkan para manajer diciptakan oleh korporasi. Para pengusaha mencuri dari korporasi sedangkan manajer mencuri untuk kepentingan korporasi ". Secara jujur harus diakui, bahwa bukti dari fenomena ini dapat terlihat pada setiap sektor dan bidang kegiatan manusia. Skandal dan manipulasi baik secara laten atau manifes telah umum berlangsung di beberapa organisasi. ${ }^{2}$ Korupsi misalnya, telah menjadi rangkaian cerita sehari-hari. Fundamentalisme dan ekstremisme telah melahirkan terorisme dan militansi.Kecenderungan radikalisme ini tidak dapat ditampung oleh konsep-konsep kepemimpinan dan manajemen konvensional.

Dalam organisasi formal, kegiatan para supervisor, kepala Sekolah, guru, manajer, eksekutif, pejabat, administrator dan lain sebagainya kewenangannya berasal dari undang-undang dan aturan. Sementara esensi kewenangan seorang pemimpin seharusnya lahir dari nilai-nilai rohani dan jasmani mereka. Para manajer perlu menyerap kualitas esensial kepemimpinan yang akan meningkatkan efektivitas mereka. Gandhi, Mao, Lincoln, dan bahkan Khomaeni adalah para pemimpin dengan sejumlah cita-cita dan nilai-nilai. ${ }^{3}$ Pemimpin dan manajer seyogyanya merupakan penguasa bijak dengan nilai-nilai luhur dan cita-cita. Dalam organisasi formal, baik pemerintah dan non-pemerintah, yang diwakili oleh para pemimpin politik, ekonomi, bisnis, sosial, pendidikan, ilmu pengetahuan, agama dan sebagainya, bahkan supervisor, pengawas, manajer, eksekutif, pejabat dan administrator memperoleh kewenangannya berdasarkan konstitusi, aturan, dan konvensi.

Dampak dari spiritualitas terhadap individu adalah terbentuknya mentalitas baru yang bercirikan orientasi yang lebih holistik, altruistik, pelayanan kepada manusia, komitmen pada kebenaran, dan bentuk-bentuk perilaku luhur lainnya, serta kesadaran diri (self awareness). Pengendalian diri, optimisme, dorongan berbuat yang terbaik, dan prakarsa, kesemuanya ini terkait dengan self leadership and management, yang juga adalah dampak lain dari spiritualitas. Mentalitas semacam itu sangat penting bagi akselerasi perubahan organisasi pendidi-

\footnotetext{
${ }^{2}$ Faisal Afif, Kepemimpinan Dan Manajemen Berbasis Spiritual, (Bandung: Unpad, 2014)

${ }^{3}$ Asmaun Hasan, Religiusitas Peerguruan Tinggi, (Malang: UIN malang Press; 2011) 5
}

200 | FENOMENA, Vol.18 No. 2Oktober 2019 
kan. ${ }^{4}$ Sesungguhnya tidak ada peningkatan produktivitas jika tidak ada perbaikan dalam self-awareness ataupun self-leadership and management.

Produktivitas merupakan fungsi dari social-management. Sebelum bisa efektif mengelola transaksi dan/atau interaksi antar individu dan tim kerja secara timbal balik, diperlukan terlebih dahulu manajemen diri sendiri yang efektif (selfleadership and management). Dengan demikian, efektivitas sosial kepemimpinan dan manajemen memerlukan efektivitas dalam self-leadership and management. Untuk memahami self-leadership and management ini dan dampaknya terhadap socialleadership and management dan produktivitas organisasi, penting terlebih dahulu untuk difahami kecerdasan spiritual dan kecerdasan emosional secara individual, yakni dua bentuk kecerdasan selain kecerdasan intelegensi, yang belakangan ini dipandang menentukan kinerja individu. ${ }^{5}$ Dua bentuk kecerdasan ini, selain terkait satu dengan lainnya, juga sangat penting dalam meningkatkan efektifitas kepemimpinan dan manajemen diri dan sosial, dan dalam konteks ini adalah efektivitas dalam mencapai keberhasilan leadership and management organization itu sendiri, baik pada organisasi bisnis dan bahkan juga pada organisasi publik.

\section{Pembahasan}

\section{Kepemipinan Spiritual}

Manusia sebagai makhluk sosial senantiasa berinteraksi dengan manusia lain di dalam kehidupan sehari-hari. Dalam interaksi ini akan terjadi proses saling mempengaruhi antara satu dengan yang lainnya. Dalam proses saling mempengaruhi tersebut akan ditemukan individu-individu yang memberikan pengaruh yang lebih besar dari pada yang lainnya. Individu-individu yang mampu memberikan pengaruh yang lebih besar tersebut dapat dikatakan memiliki sifat kepemimpinan yang lebih tinggi dan kuat. Setiap individu adalah pemimpin, apapun profesi dan pekerjaannya sesuai dengan fitrahnya. Hal ini sejalan dengan Hadis Rasulullah SAW yang berbunyi: "Setiap dari kalian adalah pemimpin dan setiap pemimpin akan dimintai pertanggungjawabannya atas kepemimpinannya" (HR. Bukhari dan Muslim).

Kualitas kepemimpinan kepala sekolah, guru merupakan determinan kualitas proses pembelajaran. Kualitas proses pembelajaran yang rendah meru-

\footnotetext{
4 Jung, Dong I.(2001). Transformational and transactional leadership and their effectson creativity in groups. Creativity Reseacrh Journal, 2000-2001,vol. 13 No. 2, 185-195.

${ }^{5}$ Zohar, SQ: Memanfaatkan kecerdasan spiritual dalam berpikir integralistik dan holistik untuk memaknai kehidupan.( Bandung : Mizan, 2001) 21
}

FENOMENA, Vol.18 No. 2Oktober 2019 | 201 
pakan salah satu cerminan kualitas kepemimpinan. Kepala sekolah atau guru yang tidak memiliki kepemimpinan yang kuat sulit diharapkan untuk menghasilkan proses pembelajaran yang baik. Proses pembelajaran yang baik memubutuhkan perencanaan, pelaksanaan dan evaluasi yang diperbaiki secara terus menerus. ${ }^{6}$

Proses pembelajaran yang baik membutuhkan hubungan yang baik antara tenaga pendidik dengan murid. Proses pembelajaran yang baik mebutuhkan motivasi peserta didik yang tinggi, dan kemampuan untuk memotivasi mahasiswa merupakan salah satu esensi sifat kepemimpinan.Kecerdasan emosional dan spiritual merupakan elemen esensial bagi seorang pemimpin. Kecerdasan emosional merupakan kecerdasan yang memungkinkan seorang pemimpin untuk membangun hubungan yang positif dengan orang yang dipimpinnya. Kecerdasan spiritual akan mengarahkan seseorang untuk senantiasa menjalankan kecerdasan intelektual dan spiritualnya pada kebaikan. Kecerdasan intelektual dan emosional yang tidak didasari oleh kecerdasan spiritual berpotensi untuk menggunakan kecerdasannya tersebut pada jalan yang salah. Dengan demikian pemimpin yang baik memerlukan ketiga jenis kecerdasan tersebut (IQ,EQ dan SQ) secara seimbang.

\section{Kepemimpinan Spritual dan Pengaruhnya dalam Pendidkan dan pem- belajaran}

Budaya sekolah yang sehat ternyata berkorelasi kuat dengan meningkatnya motivasi dan prestasi para siswa dan berkorelasi kuat juga dengan produktivitas kerja dan kepuasan para guru. Budaya sekolah juga mempengaruhi sikap guru terhadap poekerjaan mereka sehingga akan memberi implikasi kepada mutu. Dalam studi yang dilakukan oleh Cheng (2003) diketahui bahwa budaya sekolah yang lebih kuat telah meningkatkan motivasi kerja guru. ${ }^{7}$ Dalam sebuah lingkungan dengan ideologi organisasi yang kuat, partisipasi yang dihayati bersama, kepemimpinan yang kharismatik dan keakraban, menyebabkan para guru merasakan kepuasan kerja yang lebih tinggi dan peningkatan produktivitas. Dalam rangka mengembangkan budaya sekolah yang berkenaan dengan tugas dari kepala sekolah selaku pimpinan di sekolah. Hendaknya kepala sekolah mampu melihat lingkungan sekolahnya secara keseluruhan. Sehingga mampu

\footnotetext{
${ }^{6}$ Madhi, Jamal. Menjadi Pemimpin yang Efektif \& Berpengaruh, tinjauan Manajem Kepemimpinan Islam, (Bandung. PT. Syaamil Cipta Medi, 2001) 43

${ }^{7}$ Madhi, Jamal. Menjadi Pemimpin yang Efektif \& Berpengaruh, tinjauan Manajem Kepemimpinan Islam, (Bandung. PT. Syaamil Cipta Medi, 2001) 43
}

202 | FENOMENA, Vol.18 No. 2 Oktober 2019 
memahami masalah-masalah yang dihadapi oleh warga sekolahnya. Maka dari itu melalui pemahaman mengenai budaya organisasi sekolah akan mampu memberikan pemahaman mengenai nilai, keyakinan dan sikap diantara warga sekolah sehingga bisa meningkatkan hubungan yang harmonis diantara warga sekolah.Mutu pendidikan atau mutu sekolah tertuju pada mutu lulusan. Merupakan suatu yang mustahil, pendidikan atau sekolah menghasilkan lulusan yang bermutu, jika tidak melalui proses pendidikan yang bermutu pula. Merupakan sesuatu yang mustahil pula, terjadi proses pendidikan yang bermutu jika tidak didukung oleh faktor-faktor penunjang proses pendidikan yang bermutu pula.

Spritualisme akan mendorong lahirnya sifat-sifat positip bagi seseorang dalam menjalankan tugasnya, termasuk dalam proses pendidikan dan pembelajaran. ${ }^{8}$

\section{a. Kepemipinan spiritual menorong tumbuhnya Integritas atau ke- jujuran}

Kejujuran pemipin baik guru maupun kepala sekolah akan menghindari terjadinya "kecelakaan" dalam pendidikan. Kecelakaan dalam pendidikan antara lain terjadi karena adanya ketidakjujuran dalam pelaksanaan pendidikan, antara lain ketidakjujuran dalam penilaian, ketidakjujuran pemberian sanksi, ketidakjujuran dalam perencanaan.

Ketidakjujuran merupakan kecelakaan dalam dunia pendidikan yang dapat menyebabkan dampak negatip begitu luas dalam dunia pendidikan kita dewasa ini. Ketidakjujuran antara lain dapat terjadinya karena kurangnya kecerdasan spiritual pada beebagai pelaku dalam dunia pendidikan, antara lain pada pengambil kebijakan, tenaga pendidik, murid dan masyarakat sendiri.

\section{b. Kepemipina spiritual menimbulkan energi atau semangat}

Kepemipinan kepala sekolah ataupun guru dalam proses pendidikan yang memiliki kecerdasan spiritual akan senantiasa mendapatkan energi dan semangat dalam menjalankan tugasnya. Energi tersebut dapat timbul karena guru yang demikian mandapatkan kebahagiaan dari apa yang diberikannya pada peserta didik. Kebahagiaan yang dirasakan tersebut merupakan kebahagiaan spiritual, yakni kebahagiaan tatkala potensi yang dimilikinya dapat memberikan manfaat bagi orang lain dalam hal ini adalah murid. Dengan demikian kepala sekolah, pendidik yang memiliki kecerdasan spiritual yang tinggi akan memberikan potensinya secara optimal pada tugasnya tanpa tuntutan yang berlebihan terhadap imbalan, karena kebahagiaanya bukan terletak pada imbalan yang

\footnotetext{
${ }^{8}$ Manshur, Sistem Nilai dalam Budaya Organisasi,( Jember; STAIN Press, 2014) 37
} 
diterimanya tetapi justru ketika dia dapat mengeluarkan potensinya untuk maslahatan orang lain.

\section{c. Kepemipinan spiritual melahirkan inspirasi atau ide dan inisiatif}

Kepala Sekolah atau Guru yang memiliki kecerdasan spiritual yang tinggi senantiasa memperoleh inspirasi dan inisiatif dalam menjalankan tugasnya. Inspirasi dan inisiatif tersebut dapat lahir karena kepala sekolah ataupun guru dengan spiritualitas yang tinggi akan mampu meminimalkan kepentingankepentingan pribadi yang dangkal atau dengan kata lain kepala sekolah atau tenaga pendidik tersebut dapat men "zero" kan dirinya, yaitu dapat menfokuskan pemikirannya pada pelaksanaan tugasnya tanpa terbelenggu oleh kepentingan-kepentingan dangkal yang bersifat materialis.

d. Kepemipinan spiritual menentun untuk menjadi wisdom atau bijaksana

Kepal sekolah atau Guru yang bijaksana mampu menyelesaikan konflik dan persoalan dengan sebaik-baiknya. Seperti diketahui bahwa konflik dalam sebuah organisasi merupakan suatu keniscayaan. ${ }^{9}$ Setiap interaksi dua orang atau lebih sewaktu-waktu dapat menimbulkan konflik. Dalam dunia pendidikan konflik dapat terjadi antara guru, kepala sekolah dengan murid, antara sesama murid, antara murid dengan keluarganya atau konflik yang terjadi dalam diri individu-individu tersebut. Penyelesaian konflik yang baik menuntut sikap yang bijaksana. Penyelesaian konflik yang bijaksana akan melahirkan perubahanperubahan ke arah yang lebih baik. Dengan demikian konflik itu sendiri dapat memiliki segi fungsional bila dikelola dengan baik.

e. Kepemipinan spiritual mendorong keberanian dalam mengambil keputusan

Kecerdasan spiritual akan melahirkan keberanian dalam mengambil keputusan. Kepala sekolah atau guru yang melaksanakan tidak akan terbebani dengan rasa takut terhadap konsekuensi hasil keputusannya Karena keputusannya telah melalui pertimbangan yang matang dan objektif. Keputusan yang diambil dengan pertimbangan matang dan objektif akan dapat diterima oleh pihak yang terkena akibat keputusan tersebut

\section{Kesimpulan}

Untuk membangun lembaga madrasah baik (good school), bukan sekedar membutuhkan berbagai teori modernisasi dan pemberdayaan, melainkan usaha

\footnotetext{
${ }^{9}$ Khusnuridlo, Standar Nasional Pendidikan; Manajemen Pendidik dan Kependidikan (Jember; STAIN Jember Press, 2013) 23
}

204 | FENOMENA, Vol.18 No. 2 Oktober 2019 
kerja keras lahir dan batin untuk memobilisasi segala sumber daya untuk mencapai suatu cita-cita bersama, suci dan luhur. Dengan demikian merupakan kata kunci (key word) untuk merubah kondisi pendidikan Islam dari tidak diminati menjadi berprestasi, dari tidak berkualitas menjadi berkualitas, dari tidak berdaya menjadi berdaya. Beratnya perjuangan untuk melakukan perubahan terhadap pendidikan Islam disebabkan kondisi pendidikan Islam yang sebagian besar menghadapi siklus negatif atau terbelenggu oleh lingkaran setan ketidakberdayaan. Berdasarkan fenomena tersebut, pembaharuan suatu lembaga pendidikan perlu lebih ditekankan pada faktor budaya yang antara lain berupa kepemimpinan spiritual yang kuat. Kepemimpinan pendidikan yang kuat adalah kepemimpinan yang visioner, mampu membangun budaya dan proses organisasi yang efektif dan iklim pembelajaran yang kondusif.

\section{DAFTAR PUSTAKA}

Hersey, Paul \& Blanchard, Kenneth H. Management of organizational behavior: Utilizing human resources, 4thEd. (New Jersey : Prentice Hall, Inc.,Engelwood Cliffs, 1982)

Jung, Dong I. Transformational and transactional leadership and their effectson creativity in groups. Creativity Reseacrh Journal, 2000-2001,vol. 13 No. 2, 185-195.

Khusnuridlo, Moh, Standar Nasional Pendidikan : Manajemn Tenaga Pendidik dan Kependidikan, (Jember; STAIN Press, 2013)

Madhi, Jamal. Menjadi Pemimpin yang Efektif \& Berpengaruh, tinjanan Manajem Kepemimpinan Islam, (Bandung. PT. Syaamil Cipta Media, 2001)

Manshur, Sistem Nilai dalam Budaya Organisasi, ( Jember: STAIN Press, 2013)

Robbins S., Perilaku Organisasi: Konsep, Kontroversi dan Aplikasi. (San Diego State University, diterbitkan oleh PT Prenhalinddo, Jakarta, 1996)

Sahlan, Asmuni, Religiusitas Perguruan Tinggi, (Malang: UIN Malang Press, 2012)

Sahlan, Asmuni. Religiusitas Perguruan Tinggi, (Malang: UIN Malang Press, 2012)

Segal, Jeanne. Meningkatkan Kecerdasan Emosional. (Jakarta. Vitra Aksara,1997)

Suharto, Babun, Marketing Pendidikan, ( Yogyakarta: Lkis, 2015)

Terry, George R. Prinsip-prinsip Manajemen (terjemahan oleh J.Smith DFM) (Jakarta. Bumi Aksara, 1993)

Zohar, Danah dan Ian Marshall. SQ: Memanfaatkan kecerdasan spiritual dalam berpikir integralistik dan bolistik untuk memaknai kebidupan. (Bandung : Mizan, 2001)

Zohar, Danah. Spiritual Capital (terjemahan Helmi Mustofa). (Bandung,Tanpa Penerbit, 2005) 